\title{
A role for pancreatic beta-cell secretory hyperresponsiveness in catch-up growth hyperinsulinemia: Relevance to thrifty catch-up fat phenotype and risks for type 2 diabetes
}

Marina Casimir ${ }^{2 \dagger}$, Paula B de Andrade ${ }^{1 \dagger}$, Asllan Gjinovci $^{2}$, Jean-Pierre Montani ${ }^{1}$, Pierre Maechler ${ }^{2 \dagger}$, Abdul G Dulloo ${ }^{1,3^{*}+}$

\begin{abstract}
Current notions about mechanisms by which catch-up growth predisposes to later type 2 diabetes center upon those that link hyperinsulinemia with an accelerated rate of fat deposition (catch-up fat). Using a rat model of semistarvation-refeeding in which catch-up fat is driven solely by elevated metabolic efficiency associated with hyperinsulinemia, we previously reported that insulin-stimulated glucose utilization is diminished in skeletal muscle but increased in white adipose tissue. Here, we investigated the possibility that hyperinsulinemia during catch-up fat can be contributed by changes in the secretory response of pancreatic beta-cells to glucose. Using the rat model of semistarvation-refeeding showing catch-up fat and hyperinsulinemia, we compared isocalorically refed and control groups for potential differences in pancreatic morphology and in glucose-stimulated insulin secretion during in situ pancreas perfusions as well as ex vivo isolated islet perifusions. Between refed and control animals, no differences were found in islet morphology, insulin content, and the secretory responses of perifused isolated islets upon glucose stimulation. By contrast, the rates of insulin secretion from in situ perfused pancreas showed that raising glucose from 2.8 to $16.7 \mathrm{mmol} / \mathrm{l}$ produced a much more pronounced increase in insulin release in refed than in control groups $(p<0.01)$. These results indicate a role for islet secretory hyperresponsiveness to glucose in the thrifty mechanisms that drive catch-up fat through glucose redistribution between skeletal muscle and adipose tissue. Such beta-cell hyperresponsiveness to glucose may be a key event in the link between catch-up growth, hyperinsulinemia and risks for later type 2 diabetes.
\end{abstract}

\section{Introduction}

A large body of evidence indicate that subjects who had low birth weight or who showed reduced growth rate during childhood, but who subsequently showed catchup growth, have higher susceptibility for type 2 diabetes or cardiovascular diseases later in life [1-5]. While the nature of this association between catch-up growth and later disease risks remains obscure [6], it is intricately linked to the state of hyperinsulinemia and accelerated recovery of body fat (catch-up fat) that characterizes catch-up growth [5-7]. There is a well-described rat

\footnotetext{
* Correspondence: abdul.dulloo@unifr.ch

+ Contributed equally

'Department of Medicine / Physiology, University of Fribourg, Switzerland Full list of author information is available at the end of the article
}

model of semistarvation-refeeding in which catch-up fat and hyperinsulinemia occur in absence of hyperphagia and could be linked to an elevated metabolic efficiency due to suppressed thermogenesis [8]. Using this model, we previously showed that insulin-mediated glucose utilization is diminished in skeletal muscle but enhanced in white adipose tissue [9], thereby suggesting that catchup fat is characterized by glucose redistribution from skeletal muscle to adipose tissue. The suppressed thermogenesis is thus associated with establishment of a thrifty metabolism which spares glucose for catch-up fat via coordinated induction of insulin resistance in skeletal muscle, insulin hyperresponsiveness in adipose tissue and a state of hyperinsulinemia. In this context, putative implication of insulin-secreting cells remains unknown.
C Biomed Central

() 2011 Casimir et al; licensee BioMed Central Ltd. This is an Open Access article distributed under the terms of the Creative Commons Attribution License (http://creativecommons.org/licenses/by/2.0), which permits unrestricted use, distribution, and reproduction in any medium, provided the original work is properly cited. 
Here, we tested the hypothesis that the hyperinsulinemic state of catch-up fat might also be contributed by pancreatic beta-cell hyperresponsiveness to glucose. To this end, we investigated the semistarvation-refeeding rat model for pancreatic endocrine function and morphology. In particular, the secretory responses of perfused pancreases and isolated islets were analyzed.

\section{Methods}

\section{Animals and Diet}

Male Sprague Dawley rats (Elevage Janvier, France), caged singly in a temperature-controlled room $(22 \pm$ $1^{\circ} \mathrm{C}$ ) with 12 -h light/dark cycle, were maintained on chow diet (Kliba, Cossonay, Switzerland) consisting, by energy, of $24 \%$ protein, $66 \%$ carbohydrates, and $10 \%$ fat, and had free access to tap water. Animals were maintained in accordance with our institute's regulations and guide for the care and use of laboratory animals.

\section{Design of study}

The experimental design is similar to that previously described [8]. Seven wk old rats were food-restricted at $50 \%$ of their spontaneous food intake for $2 \mathrm{wks}$, after which they were refed the same amount of chow corresponding to spontaneous chow intake of control rats matched for weight at the onset of refeeding. Under these conditions, the refed animals show similar gain in lean mass, but 2 -fold greater fat gain than controls, due to $10-13 \%$ lower energy expenditure resulting from suppressed thermogenesis [8]. Pancreatic function was assessed on day 7 of refeeding, i.e. at a time-point when, as shown in Figure 1, body fat in refed animals has not yet exceeded that of controls, and when refed animals showing catch-up fat exhibit normal glucose tolerance, but are hyperinsulinemic as judged by higher plasma insulin concentrations after a glucose load.

\section{Pancreas perfusions (in situ)}

To evaluate insulin-secretory capacity of the endocrine pancreas, refed and control rats were anesthetized with sodium pentothal and prepared for pancreas perfusion as previously described [10]. Briefly, the pancreas was perfused with a Krebs-Hank's buffer (KHB) at a constant rate of $5 \mathrm{ml} / \mathrm{min}$ via mesenteric and transileac arteries, and the perfusate was collected every minute from a catheter placed in the portal vein. After an initial equilibration period with no sample collected, the effluent was collected in 1-min fractions from the portal vein. The pancreas was perfused at $37^{\circ} \mathrm{C}$ with the KHB buffer supplemented with the following concentrations of glucose: period I (basal, last $4 \mathrm{~min}$ ) $2.8 \mathrm{mmol} / 1$ glucose, periods II and III (15 min each) $16.7 \mathrm{mmol} / \mathrm{l}$ glucose, period IV (recovery, $15 \mathrm{~min}$ ) $2.8 \mathrm{mmol} / \mathrm{l}$ glucose. Aliquots of perfusates were collected on ice and stored at $-20^{\circ} \mathrm{C}$ until insulin assay by radioimmunoassay (RIA) using rat insulin as standard.

\section{Isolated islet perifusions (ex vivo)}

To evaluate the kinetics of insulin secretion in isletperifusion experiments, pancreatic islets were isolated by collagenase digestion and handpicking from refed and control rats as described previously [11]. Isolated islets were cultured free-floating in RPMI 1640 medium before experiments. Insulin levels were determined by RIA and insulin secretion collected every min was normalized per islet number. Islet perifusions were carried out using 15 to 20 hand-picked islets per chamber of $250 \mu$ l volume thermostated at $37^{\circ} \mathrm{C}$ (Brandel, Gaithersburg, MD, USA). The flux was set at $0.5 \mathrm{ml} / \mathrm{min}$ and fractions were collected every min following a 20-min washing period at basal glucose. Rat islets were perifused with Krebs-Ringer bicarbonate HEPES buffer at basal $2.8 \mathrm{mmol} / \mathrm{l}$ glucose for $20 \mathrm{~min}$, then stimulated with $8.0 \mathrm{mmol} / \mathrm{l}$ glucose $(20 \mathrm{~min})$ and $16.7 \mathrm{mmol} / \mathrm{l} \mathrm{glu}$ cose $(20 \mathrm{~min})$, returning to $2.8 \mathrm{mmol} / \mathrm{l}$ glucose (last 10 $\min )$.

\section{Immunohistochemistry}

Pancreata were harvested in cold PBS and treated overnight at $4^{\circ} \mathrm{C}$ in $4 \%$ paraformaldehyde before embedding in paraffin and $5 \mu \mathrm{m}$-thick tissue sections were mounted on adhesive-coated slides. Pancreata sections were incubated with a diluted primary antibody for 2 hours at room temperature, and with an appropriate Cy3(Jackson ImmunoResearch Laboratories, Inc, WestGrove, PA, USA) or ALEXA-conjugated (Molecular Probes, Inc., Eugene, OR, USA) anti IgG serum for 1 hour. The antibodies and their dilution used in the present analysis were as follows: guinea pig anti-insulin (Dako, Carpinteria, CA, USA; dilution 1/400), rabbit anti-glucagon (Dako, Carpinteria, CA, USA; dilution 1/100). Sections were analyzed on a Zeiss Axiophot microscope equipped with an Axiocam color CCD camera (Carl Zeiss, Feldbach, Switzerland).

\section{Statistics}

Data are expressed as mean $\pm \mathrm{SE}$, and were analyzed by either unpaired t-test or analysis of variance, using computer software STATISTIK 8 (Analytical Software, St. Paul, Minnesota).

\section{Results}

\section{Pancreatic perfusions (in situ)}

Figure 2 (panel a) shows the profiles of insulin secretion assessed by in situ perfusion of intact pancreas from refed and control animals on day 7 of refeeding. Raising glucose (Glc) from 2.8 to $16.7 \mathrm{mmol} / \mathrm{l}$ led to a much more pronounced increase in insulin release as a 


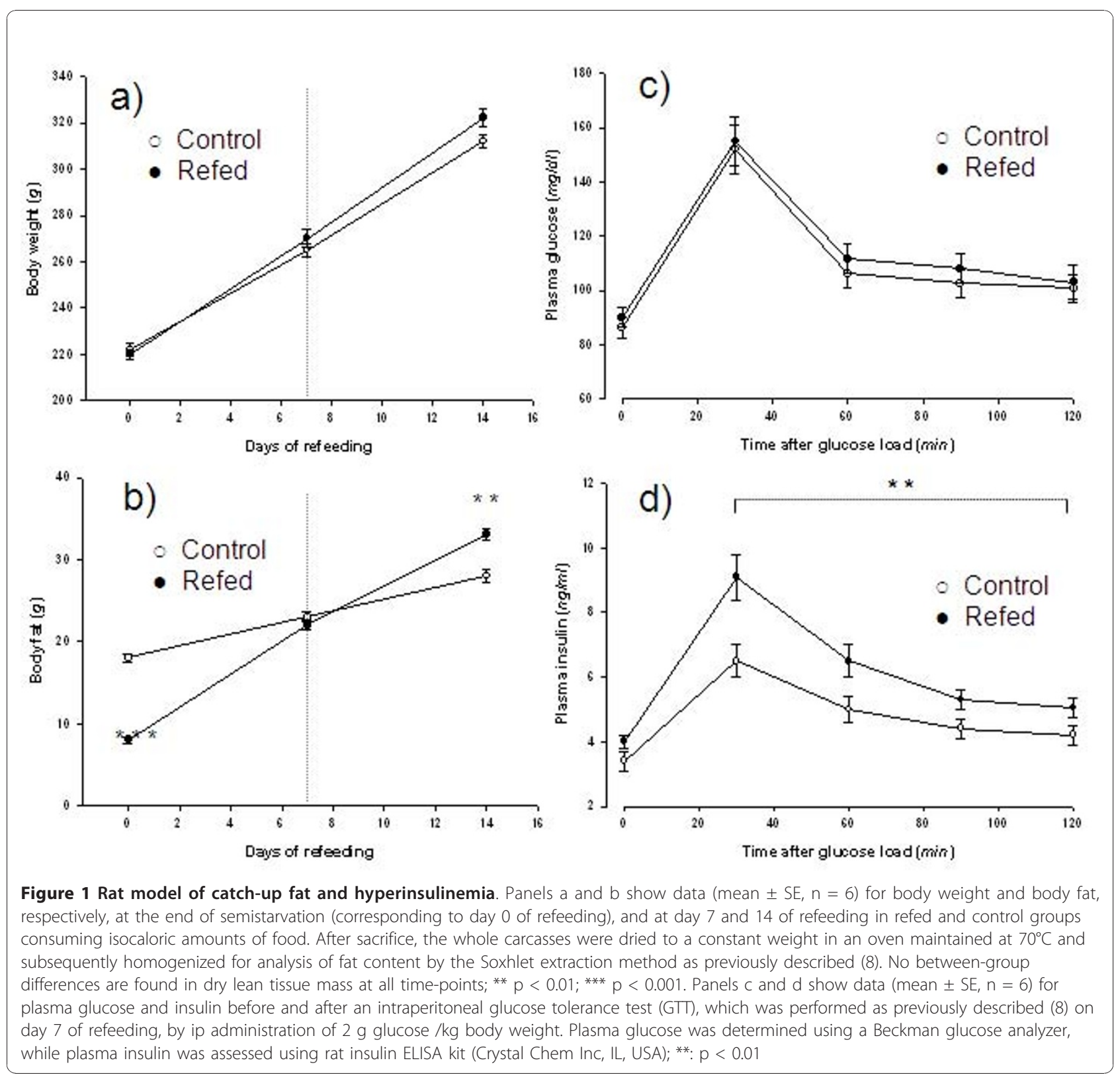

function of time in refed rats than in controls. The area under the curve (AUC), calculated after subtraction of basal release and shown in Figure 2 (panel b), was greater by 3 - and 4-fold in the first and second $15 \mathrm{~min}$ period respectively, in refed than in control animals $(\mathrm{P}<$ 0.01 , by Student's $t$-test). During the recovery period (upon shifting back to $2.8 \mathrm{mmol} / \mathrm{l}$ glucose), the differences in insulin secretion between the two groups were markedly attenuated and no longer significant.

\section{Isolated islet perifusions (ex vivo)}

The kinetics of insulin secretion in islet-perifusion experiments, shown in Figure 2 (panel $\mathrm{c}$ and $\mathrm{d}$ ) indicated that, once isolated, islets from refed and control animals responded similarly to 8.0 and 16.7 $\mathrm{mmol} / \mathrm{l}$ glucose.

\section{Islets and whole pancreas}

No between-group differences were found in wet weight of fresh pancreases $(2.77 \pm 0.58$ vs $2.49 \pm 0.55 \mathrm{~g})$ and in total insulin content $(342 \pm 55$ vs $340 \pm 58 \mu \mathrm{g}$ insulin per g tissue) comparing control and refed animals respectively. Furthermore, immunohistochemistry revealed that islets of refed rats were normal, exhibiting similar beta-cell distribution and size than controls (Figure 3). 

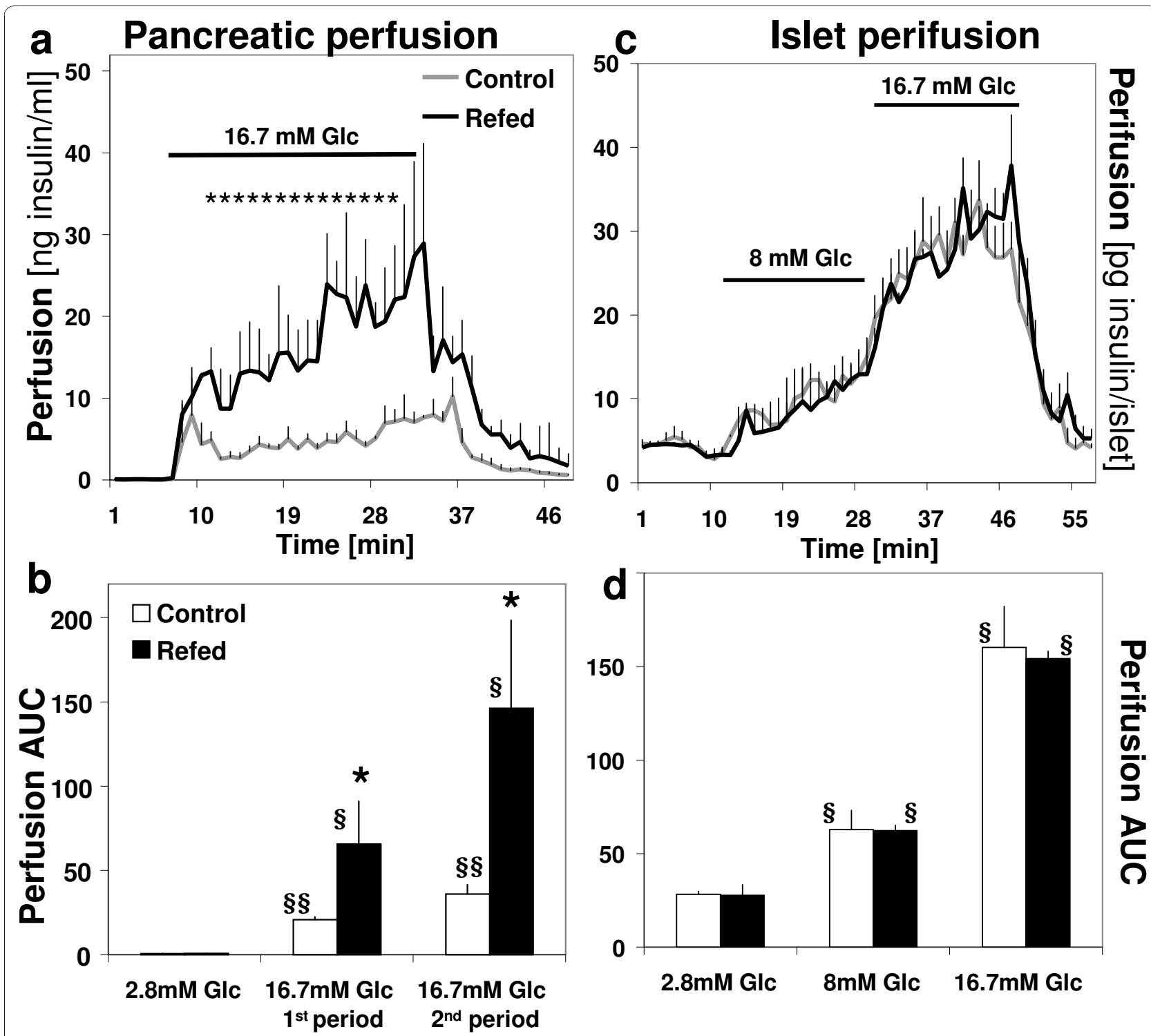

Figure 2 Kinetics of insulin secretion. Panel a shows the kinetics of insulin secretion from in situ perfusion of pancreas in response to glucose $(G \mid c)$ in refed and control animals $(n=6)$ on day 7 of refeeding, first in response to $2.8 \mathrm{mM}$ glucose (baseline), followed by two successive periods lasting $15 \mathrm{~min}$ each in response to $16.7 \mathrm{mmol} / \mathrm{l}$ glucose before switching back to $2.8 \mathrm{mmol} / \mathrm{l}$ glucose. Panel b shows the area under the curve (AUC) for each time-period, calculated after subtraction of basal release. All values are mean \pm SE. Symbols for statistical significance of differences are as follows: panel a: ${ }^{*} p<0.05$ (at least) between refed and control for corresponding time points; Panel b: * $p<0.05$ : betweengroup comparison (refed vs control) for AUC within $1^{\text {st }}$ or $2^{\text {nd }}$ period; $\S p<0.05$; $\S \S p<0.01$ : within-group comparison between $16.7 \mathrm{mM} \mathrm{Glc} \mathrm{or}$ $8 \mathrm{mM}$ relative to basal $2.8 \mathrm{mM} \mathrm{Glc}$. Panel c indicates the kinetics of insulin secretion from ex vivo perifusion of islets isolated from pancreases of refed and control groups $(n=5)$ on day 7 of refeeding, first in response to $2.8 \mathrm{mmol} / \mathrm{l}$ glucose (baseline), followed by two successive periods of $17 \mathrm{~min}$ with 8 and $16.7 \mathrm{mmol} / \mathrm{l}$ glucose, respectively, before switching back to $2.8 \mathrm{mmol} / \mathrm{l}$ glucose; panel d shows the AUC for each time-period, calculated after subtraction of basal release. Panel d shows the area under the curve (AUC) for each time-period, calculated after subtraction of basal release All values are mean \pm SE. Symbols for statistical significance of differences in panel b are as follows: $\S p<0.05$ : within-group comparison between $16.7 \mathrm{mM}$ Glc or $8 \mathrm{mM}$ Glc relative to basal $2.8 \mathrm{mM}$ Glc

Plasma hormones

No between-group differences were found in plasma concentrations of glucagon-like peptide 1, gastric inhibitory peptide, or leptin (Table 1). By contrast, plasma adiponectin concentrations were higher in the refed animals than in controls $(\mathrm{p}<0.01)$.

\section{Discussion}

Beta-cell function was investigated in a rat model of semistarvation-refeeding in which a high metabolic efficiency for body fat recovery (i.e., thrifty metabolism driving catch-up fat) is intricately associated with hyperinsulinemia [8]. Data show that the hyperinsulinemic 


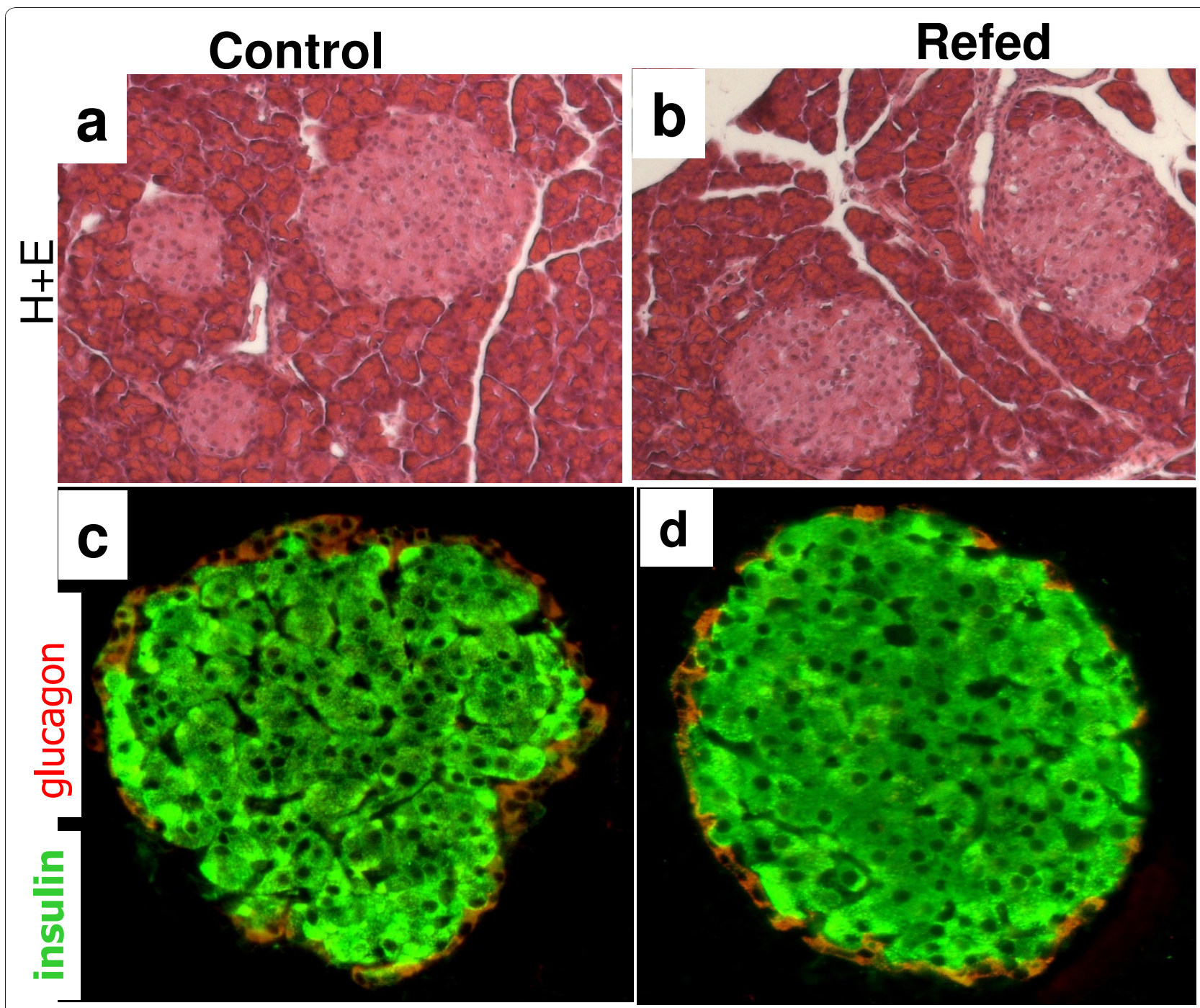

Figure 3 Pancreatic islet morphology and insulin content. Panels $a$ and $b$ are pancreata sections stained with hematoxylin and eosin $(H+E)$ showing islets and acinar cells in control and refed rats, respectively. Panel c and $\mathrm{d}$ are immunostainings of insulin (in green) and glucagon (in red) showing representative islets from control and refed rats, respectively.

state of catch-up growth is characterized at the beta-cell level by enhanced secretory response to glucose stimulation. No difference was observed between refed and controls in the weight of the pancreas, pancreatic islet morphology or insulin content. Accordingly, pancreatic

Table 1 Plasma concentrations of hormones on day 7 of refeeding

\begin{tabular}{llll}
\hline & Control & Refed & t-test \\
\hline Glucagon-like peptide-1 $(\mathrm{ng} / \mathrm{ml})$ & $0.28 \pm 0.02$ & $0.24 \pm 0.02$ & $\mathrm{NS}$ \\
Gastric inhibitory peptide $(\mathrm{ng} / \mathrm{ml})$ & $0.49 \pm 0.04$ & $0.55 \pm 0.07$ & $\mathrm{NS}$ \\
Leptin $(\mathrm{ng} / \mathrm{ml})$ & $1.91 \pm 0.10$ & $2.17 \pm 0.18$ & $\mathrm{NS}$ \\
Adiponectin $(\mathrm{\mu g} / \mathrm{ml})$ & $7.34 \pm 0.41$ & $11.7 \pm 1.60$ & $\mathrm{p}<0.01$
\end{tabular}

All values are mean $\pm S E(n=6)$; NS: no significant differences.

The hormones were assayed by commercial ELISA kits from tail blood collected after a 5-6 $\mathrm{h}$ fast. insulin hypersecretion during catch-up growth cannot be attributed to an increase in beta-cell mass or pancreatic insulin content and hence in functional cells, but rather resides primarily in an in situ beta-cell hyperresponsiveness.

Interestingly, such insulin hypersecretion during catch-up growth was observed in the in situ pancreatic perfusion preparation, although not in isolated islets. Therefore, hyperresponsiveness cannot be explained by intra-cellular alterations in metabolism-secretion coupling per se nor in the insulin exocytosis mechanisms. The observed phenomenon is likely to reside in differential modulation of the secretory response, possibly through negative modulators of insulin secretion being repressed during catch-up growth, resulting in the observed hyperresponsiveness of the pancreatic response 
to glucose. Such in situ islet tuning could be contributed by neuro-hormonal effectors (e.g glucagon-like peptide 1 [12]), paracrine systems (e.g. dopamine [13,14]), or even composition of surrounding fatty acids [15], all these factors being lost once islets are isolated.

The pancreatic insulin hypersecretion during catch-up growth is, however, unlikely be attributed to glucagonlike peptide 1 and gastric inhibitory peptide since these incretins did not differ in refed and control groups in the post-absorptive state (Table 1) nor after a glucose load (data not shown). It is also unlikely to be consequential to excess adiposity and the associated elevation in circulating leptin since our between-group comparison was conducted on day 7 of refeeding, i.e. at a time-point when body fat and plasma leptin in the refed animals had not yet exceeded those of controls (see Figure 1, panel $\mathrm{b}$ and Table 1), respectively. Whether our findings of an elevated plasma adiponectin in the refed group versus controls (Table 1) can be implicated in the increased pancreatic hyperresponsiveness to glucose is at present unknown. This is an avenue for further research, particularly in the light of emerging evidence that adiponectin may act directly on pancreatic beta-cells to enhance insulin secretion [16].

Whatever the mechanisms that lead to such beta-cell hyperresponsiveness to glucose during catch-up growth, its demonstration in a rat model in which catch-up fat is driven solely by suppressed thermogenesis (and not hyperphagia) suggests a role for pancreatic islets in the thrifty mechanisms that drive catch-up fat through glucose redistribution between skeletal muscle and adipose tissue $[8,9,17,18]$. This is depicted in a conceptual model presented in the Figure 4.

An enhanced beta-cell function, as evidenced by an increased insulin release in response to glucose stimulation, has been observed early in the pathogenesis of type 2 diabetes in animal models [19-21]. It has also been shown to be an early characteristic of ethnic groups and people with normal glucose tolerance at higher risks for diabetes [22-27], and is embodied in the concept that $\beta$-cell hyperfunction is an early stage in the progression to $\beta$-cell failure [28]. The pancreatic $\beta$-cell hyperresponsiveness to

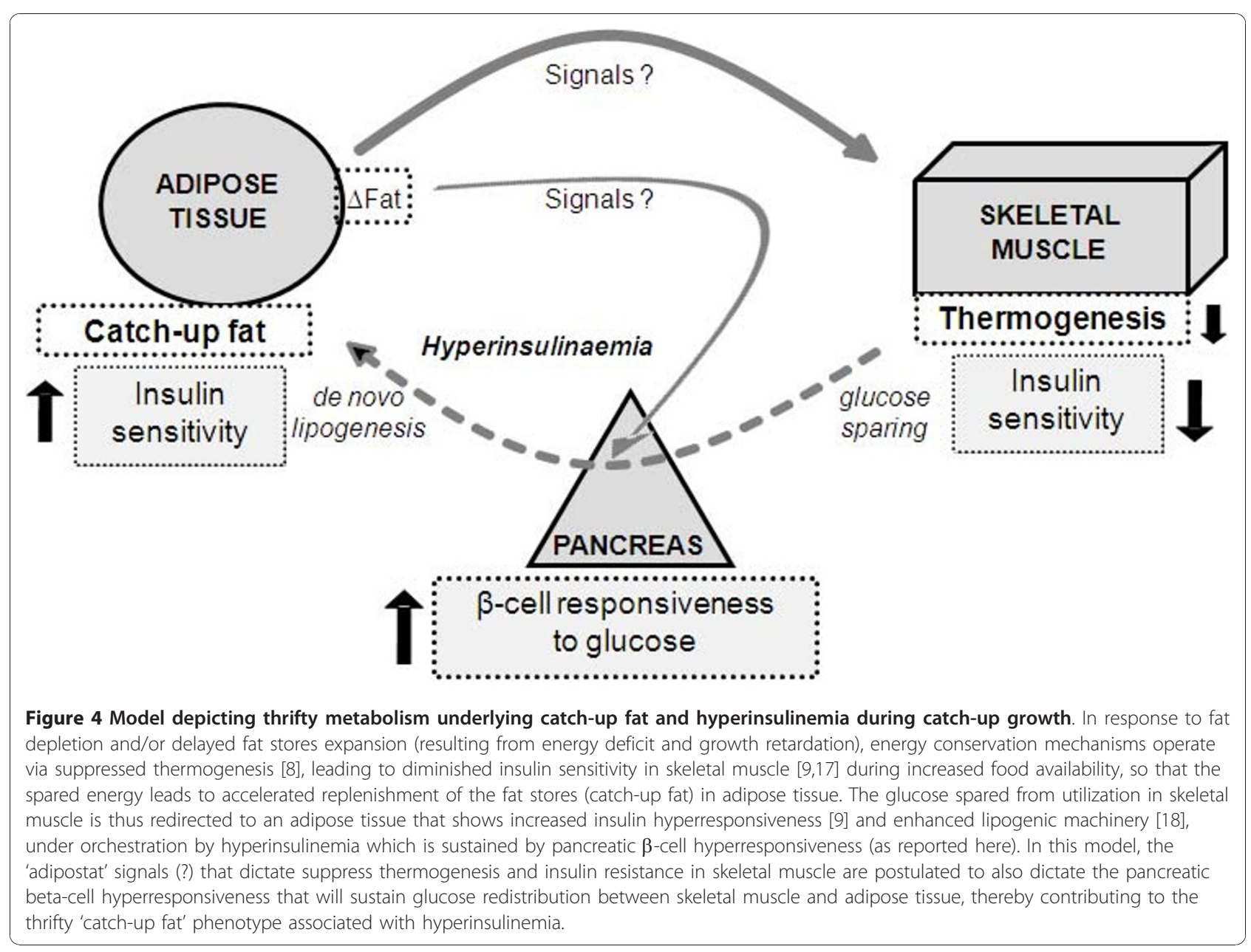


glucose during catch-up fat may therefore be a key component in the link between catch-up growth and later risks for type 2 diabetes.

\section{Acknowledgements}

This work was supported by the Swiss National Science Foundation, (grants \# 3200BO-113634 to AGD and \#310030-120584 to PM).

\section{Author details}

'Department of Medicine / Physiology, University of Fribourg, Switzerland. ${ }^{2}$ Department of Cell Physiology and Metabolism, University of Geneva, Switzerland. ${ }^{3}$ Department of Medicine / Physiology, University of Fribourg, Rue du Musée 5, CH-1700 Fribourg, Switzerland.

\section{Authors' contributions}

$M C$ researched data, contributed to discussion and reviewed/edited manuscript. PMdA researched data, contributed to discussion and reviewed/ edited manuscript. AG researched data. JPM contributed to discussion and reviewed/edited manuscript. PM designed the study, contributed to discussion and wrote manuscript: AGD designed the study, contributed to discussion and wrote manuscript. All authors read and approved the final manuscript.

\section{Competing interests}

The authors declare that they have no competing interests.

Received: 12 November 2010 Accepted: 18 January 2011 Published: 18 January 2011

\section{References}

1. Eriksson JG, Forsen T, Tuomilehto J, Winter PD, Osmond C, Barker DJP: Catch-up growth in childhood and death from coronary heart disease: longitudinal study. BMJ 1999, 318:427-431.

2. Cianfarani $S$, Germani D, Branca F: Low birth weight and adult insulin resistance: the 'catch-up growth' hypothesis. Arch Dis Child Fetal Neonatal Ed 1999, 81:F71-73.

3. Ong KKL, Ahmed ML, Emmett PM, Preece MA, Dunger DB: Association between postnatal catch-up growth and obesity in childhood: prospective cohort study. BMJ 2000, 320:967-971.

4. Ong KK, Dunger DB: Birth weight, infant growth and insulin resistance. Eur J Endocrinol 2004, 151:U131-U139.

5. Nobili V, Alisi A, Panera N, Agostoni C: Low birth weight and catch-upgrowth associated with metabolic syndrome: a ten year systematic review. Pediatr Endocrinol Rev 2008, 6:241-7.

6. Cottrell EC, Ozanne SE: Developmental programming of energy balance and the metabolic syndrome. Proc Nutr Soc 2007, 66:198-206.

7. Dulloo AG: Regulation of fat storage via suppressed thermogenesis: a thrifty phenotype that predisposes individuals with catch-up growth to insulin resistance and obesity. Hormone Research 2006, 65(3):90-7.

8. Crescenzo R, Samec S, Antic V, Rohner-Jeanrenaud F, Seydoux J, Montani JP, Dulloo AG: A role for suppressed thermogenesis favouring catch-up fat in the pathophysiology of catch-up growth. Diabetes 2003, 52:1090-1097.

9. Cettour-Rose P, Samec S, Russell AP, Summermatter S, Mainieri D, CarrilloTheander C, Montani JP, Seydoux J, Rohner-Jeanrenaud F, Dulloo AG: Redistribution of glucose from skeletal muscle to adipose tissue during catch-up fat: link between catch-up growth and later metabolic syndrome. Diabetes 2005, 54:751-6.

10. Maechler P, Gjinovci A, Wollheim CB: Implication of glutamate in the kinetics of insulin secretion in rat and mouse perfused pancreas. Diabetes 2002, 51(Suppl 1):S99-102.

11. Carobbio S, Maechler P: Sustained glucose-stimulated insulin secretion in mouse islets is not culture-dependent. Diabetologia 2004, 47:1856-7.

12. Schuit FC, Huypens P, Heimberg H, Pipeleers DG: Glucose sensing in pancreatic beta-cells: a model for the study of other glucose-regulated cells in gut, pancreas, and hypothalamus. Diabetes 2001, 50:1-11.

13. Rubí B, Ljubicic S, Pournourmohammadi S, Carobbio S, Armanet M, Bartley C, Maechler P: Dopamine D2-like receptors are expressed in pancreatic beta cells and mediate inhibition of insulin secretion. $J$ Biol Chem 2005, 280:36824-32.

14. Rubí $B$, Maechler P: Minireview: new roles for peripheral dopamine on metabolic control and tumor growth: let's seek the balance. Endocrinology 2010, 151:5570-81.

15. Frigerio F, Brun T, Bartley C, Usardi A, Bosco D, Ravnskjaer K, Mandrup S, Maechler P: Peroxisome proliferator-activated receptor alpha (PPARalpha) protects against oleate-induced INS-1E beta cell dysfunction by preserving carbohydrate metabolism. Diabetologia 2010, 53:331-40.

16. Wijesekara N, Krishnamurthy M, Bhattacharjee A, Suhail A, Sweeney G, Wheeler MB: Adiponectin-induced ERK and Akt phosphorylation protects against pancreatic beta cell apoptosis and increases insulin gene expression and secretion. J Biol Chem 2010, 285:33623-31.

17. Summermatter S, Mainieri D, Russell AP, Seydoux J, Montani JP, Buchala A, Solinas G, Dulloo AG: Thrifty metabolism that favors fat storage after caloric restriction: a role for skeletal muscle phosphatidylinositol-3kinase activity and AMP-activated protein kinase. FASEB J 2008, 22:774-85.

18. Summermatter $\mathrm{S}$, Marcelino $\mathrm{H}$, Arsenijevic $\mathrm{D}$, Buchala $\mathrm{A}$, Aprikian $\mathrm{O}$, Assimacopoulos-Jeannet F, Seydoux J, Montani JP, Solinas G, Dulloo AG: Adipose tissue plasticity during catch-up fat driven by thrifty metabolism: relevance for muscle-adipose glucose redistribution during catch-up growth. Diabetes 2009, 58:2228-37.

19. Chan CB, Pederson RA, Buchan AM, Tubesing KB, Brown JC: Gastric inhibitory polypeptide and hyperinsulinemia in the Zucker ( $\mathrm{fa} / \mathrm{fa}$ ) rat: a developmental study. Int J Obes 1985, 9:137-146.

20. Jetton TL, Lausier J, LaRock K, Trotman WE, Larmie B, Habibovic A, Peshavaria M, Leahy JL: Mechanisms of compensatory beta-cell growth in insulin-resistant rats: roles of Akt kinase. Diabetes 2005, 54:2294-2304.

21. Hansen BC, Bodkin NL: Beta-cell hyperresponsiveness: earliest event in development of diabetes in monkeys. Am J Physiol 1990, 259:R612-R617.

22. Lillioja S, Nyomba BL, Saad MF, Ferraro R, Castillo C, Bennett PH, Bogardus C: Exaggerated early insulin release and insulin resistance in a diabetes-prone population: a metabolic comparison of Pima Indians and Caucasians. J Clin Endocrinol Metab 1991, 73:866-876.

23. Stefan N, Stumvoll M, Weyer C, Bogardus C, Tataranni PA, Pratley RE: Exaggerated insulin secretion in Pima Indians and African-Americans but higher insulin resistance in Pima Indians compared to African-Americans and Caucasians. Diabet Med 2004, 21:1090-5.

24. Karter AJ, Mayer-Davis EJ, Selby JV, D'Agostino RB Jr, Haffner SM, Sholinsky P, Bergman R, Saad MF, Hamman RF: Insulin sensitivity and abdominal obesity in African-American, Hispanic, and non-Hispanic white men and women. Diabetes 1996, 45:1547-1555.

25. Arslanian S, Suprasongsin C, Janosky JE: Insulin secretion and sensitivity in black vs. white prepubertal healthy children. J Clin Endocrinol Metab 1997, 82:1923-27.

26. Gower BA, Nagy TR, Trowbridge CA, Dezenberg C, Goran MI: Fat distribution and insulin response in African-American and Caucasian children. Am J Clin Nutr 1998, 67:821-827.

27. Ku C, Gower BA, Hunter GR, Goran Ml: Racial differences in insulin secretion and sensitivity in prepubertal children: role of physical fitness and physical activity. Obes Res 2000, 8:506-515.

28. Leahy JL: Mary, Mary, quite contrary, how do your beta-cells fail? Diabetes 2008, 57:2563-4.

doi:10.1186/1743-7075-8-2

Cite this article as: Casimir et al:: A role for pancreatic beta-cell secretory hyperresponsiveness in catch-up growth hyperinsulinemia: Relevance to thrifty catch-up fat phenotype and risks for type 2 diabetes. Nutrition \& Metabolism 2011 8:2. 